\title{
THE REQUIREMENT OF A FINAL JUDGMENT OR DECREE FOR SUPREME COURT REVIEW OF STATE COURTS*
}

SINCE 1789, the Judicial Code has required that a state court "judgment or decree" be "final" to merit appellate consideration by the Supreme Court;" other sections of the Code incorporate a similar requirement for the federal court system, ${ }^{2}$ although statutory exceptions have created a more permissive framework for appeal. Since the statutory phrase, "final judgment or decree," is hardly self-defining, guidance to litigants seeking review must come largely from case law. Until last term, Supreme Court interpretations of the standard in both state and federal contexts had emphasized the need for an ultimate judgment; the principal exception, whose application appears to have been sought only in cases arising in federal courts, qualified as "final" decisions which were so dissociated from the merits as to be unreviewable when ultimate judgment on the merits was reached. ${ }^{3}$ But during that term the Court significantly altered the case law framework of finality in two cases ${ }^{4}$ construing Section 1257 of the Code, the finality requirement for review of state court decisions. The alteration has much the effect of the statutory changes which have eroded the finality requirement for the federal system, and thus substantially reduces the dissimilarity in the availability of Supreme Court review from federal and state courts. The Court said that appellate determinations of issues deemed reviewable prior to ultimate judgment by state judicial systems would henceforth be considered final within the meaning of Section 1257 if the questions raised were separate from and anterior to the merits, so as to be susceptible of independent review. This conclusion is to be reached irrespective of reviewability after ultimate judgment, provided that the party seeking review has a substantial claim of right, the denial of which threatens irreparable injury.

The final judgment rule is, at its simplest, a rule of administration limiting by reference to the stage a case has reached the number of appeals an appellate court will consider. The classic justification of finality is that it precludes pre-

*Local 438, Construction Laborers' Union v. Curry, 371 U.S. 542 (1963) ; Mercantile Nat'l Bank v. Langdeau, 371 U.S. 555 (1963).

1. 28 U.S.C. $\$ 1257$ (1958) provides in part: "Final judgments or decrees rendered by the highest court of a State in which a decision could be had, may be reviewed by the Supreme Court. ..." Subsections (1) and (2) provide for appeal; subsection (3), for certiorari.

2. E.g., 28 U.S.C. $\S 1291$ (1958), governing the appellate jurisdiction of the Courts of Appeals, requires "final decisions." See also Administrative Procedure Act $\$ 10(c)$, 60 Stat. 243 (1946), 5 U.S.C. $\$ 1009$ (1958) ("final agency action").

3. Cohen v. Beneficial Industrial Loan Corp., 337 U.S. 541 (1949). See text infra at notes 35-46.

4. Local 438, Construction Laborers' Union v. Curry, 371 U.S. 542 (1963) ; Mercantile Nat'l Bank v. Langdeau, 371 U.S. 555 (1963). 
mature and piecemeal review..$^{5}$ Deferment of appellate consideration saves judicial energy, by reducing the frequency of appeals and hence the congestion on crowded dockets. Parties to litigation may find their hopes for a speedy trial frustrated, and may be subjected to costs beyond their means, if their opponents can find an opportunity to delay through frequent interlocutory appeals. Forebearance from reviewing a decision prematurely also increases the likelihood that the appellate court will have before it all the facts and issues necessary to reach an informed judgment. In this respect, finality is analogous to the doctrine of ripeness. The record must be sufficiently complete so that issues material to the decision have been determined in the lower courts. Furthermore, there is some advantage to be gained by permitting lower courts, more familiar with the case, to correct their own errors before an appellate court intervenes.

Finality applied inexorably, however, may be self-defeating and in conflict with more important policies. For issues like jurisdiction, anterior to and independent of the merits, the availability of immediate review may in the long run save both time and expense by providing an opportunity to identify cases which need never come to trial, particularly if some means are available for selecting only those cases in which reversal is most likely. ${ }^{b}$ Nor is the avoidance of premature review a universally valid justification for finality. In some cases, where a denial of immediate review will mean a denial of any review, a rigid insistence on finality may be in the interests of neither courts nor litigants. This may often be true in labor disputes, for example, where a grant of an interlocutory injunction against a labor union will force the union to abandon forever activity which might later be found protected. In such a situation the desirability of giving relief or reaching a decision on an important question may outweigh any policy of restraint.

Extent of appealability, however, is not the only relevant consideration to be taken into account when analyzing a rule of finality. The danger in the finality rule may not come so much from an expansive definition, increasing the number of cases an appellate court will hear, as from an ill-defined rule which, lacking clarity, both lends itself to dilatory appeals and leads prudent counsel to appeal any order which may appear final, thus burdening the appellate court with a host of time-consuming preliminary determinations as to finality. For the corollary of refusal to hear cases which are not final is that

5. E.g., Canter v. American Ins. Co., 28 U.S. (3 Pet.) 307, 318 (1830), where the Court said: "... causes should not come up here in fragments, upon successive appeals ... [that] ... would occasion very great delays, and oppressive expenses." See also Cobbledick v. United States, 309 U.S. 323, 325 (1940):

... Congress from the very beginning has, by forbidding piecemeal disposition on appeal ... set itself against enfeebling judicial administration. Thereby is avoided the obstruction ... that would come from permitting the harassment and cost of a succession of separate appeals. ... To be effective, judicial administration must not be leaden-footed.

6. Note, 47 Colum. L. REv. 239, 252 (1947) ; Comment, 47 MrcH. L. REv. 233, 241 (1948). 
failure to appeal a final decision within the specified time renders the decision unappealable. ${ }^{7}$ An expanded definition of finality, therefore, will not only permit more appeals, but will also require them. In fact the number of litigants who will be deprived of review because of a failure to make a timely appeal may be small, but the threat may be sufficient to burden the courts with premature appeals.

In construing finality for review of both state and federal courts, the Supreme Court has usually emphasized that before it reviews, all issues in which the appellant can expect a decision to be rendered should have been settled. Thus, condemnation cases are not considered final until compensation has been determined, although an earlier order may have settled rights in the property. $s$ The quantitative determinations later made by the court may be as strenuously opposed as its reading of the law. In a criminal case, the sentence, rather than the verdict, is the appealable act. ${ }^{9}$ Similarly, a venue or jurisdictional determination enabling continuance of the action has invariably been held not final. ${ }^{10}$ And, where the question presented to the trial court is likely to recur

7. Dickinson v. Petroleum Conversion Corp., 338 U.S. 507 (1950); Hill v. Chicago \& Evanston R. Co., 140 U.S. 52 (1891) ; Durkin v. Mason \& Dixon Lines, Inc., 202 F.2d 425 (6th Cir. 1953). In Delta Drilling Co. v. Arnett, 186 F.2d 481 (6th Cir. 1950), though the district court had denominated its judgment "interlocutory" and the defendants claimed to have relied on this, the court of appeals held the judgment final, and that appeal of the issues involved was not timely.

Although the danger of losing the right to appeal exists, most courts probably agree with Justice Black's dissent in Dickinson v. Petroleum Conversion Corp., supra at 517:

A rational system of jurisprudence should not attach inexorable consequences to failure to guess right on a legal question for the solution of which neither statutes nor court opinions have provided even a reasonably certain guide.

Recently, in Corey v. United States, 32 U.S.L. WeEK 4038 (Dec. 9, 1963), the Supreme Court reversed the Court of Appeals (1st Cir.), which had dismissed petitioner's appeal from a criminal conviction as untimely. After his conviction, petitioner had first been sentenced for an indefinite period to permit formulation of a treatment plan (18 U.S.C. $\$ 4208$ (b) (1958)); some months later, in the proceeding from which appeal was sought, a definite sentence was entered. The court held that both impositions of sentence were appropriate times to appeal from the whole trial. The conclusion that each was sufficiently final meant that failure to appeal the conviction after the first sentencing did not bar appeal on the conviction.

8. Grays Harbor Logging Co. v. Coats-Fordney Logging Co., 243 U.S. 251 (1917); Catlin v. United States, 324 U.S. 229 (1945).

9. Berman v. United States, 302 U.S. 211, 212-13 (1937). Cf. Brady v. Maryland, 373 U.S. 83, $85 \mathrm{n.1}$ (1963), making an exception to this general rule, and Corey v. United States, supra note 7.

10. See, e.g., Cincinnati Street Ry. Co. v. Snell, 179 U.S. 395 (1900); Clinton Foods, Inc. v. United States, 188 F.2d 289 (4th Cir. 1951) ; Holdsworth v. United States, 179 F.2d 933 (1st Cir. 1950), refusing review to venue determinations. But see Paramount Pictures, Inc. v. Rodney, 186 F.2d 111 (3d Cir. 1950) (transfer order under 28 U.S.C. \$ 1404(a) (1958) reviewable by mandamus) ; Magnetic Eng'r \& Mfg. Co. v. Dings Mfg. Co., 178 F.2d 866 (2d Cir. 1950) (same); Shapiro v. Bonanza Hotel Co., Inc., 185 F.2d 777 (9th Cir. 1950) (same). 
-as where a demurrer is overruled ${ }^{11}$ or interlocutory relief is considered 12 -the great weight of authority holds its determination not final.

In some types of litigation, finality has been viewed more liberally. True, the Court has stated in obiter dictum that it is the conclusion of the whole litigation, and not arrival at some point of personal finality, which determines reviewability for a party wishing to appeal. ${ }^{13}$ But, in practice, appeal has been allowed from an order giving compensation to trustees in a foreclosure suit, ${ }^{14}$ from the dismissal of an intervening claim in a condemnation suit, ${ }^{15}$ and from an order refusing preference to a creditor seeking to intervene ${ }^{18}$-though the litigation complex of which each of these actions was a part had not yet been resolved for all of the parties therein. This disparity is not surprising. Finality is a common law concept, and English Chancery practice originally allowed appeals from both final and interlocutory decrees. ${ }^{17}$ And multi-party litigation and other circumstances in which results interim to the litigation as a whole are final for particular parties are most often equitable in character. In the

11. E.g., Missouri \& Kansas Interurban Ry. Co. v. City of Olathe, 222 U.S. 185 (1911). Pope v. Atlantic Coast Line R.R. Co., 345 U.S. 379 (1953) establishes the salutary rule that where the practical effect of an appellate decision has been to render further proceedings nugatory, such decisions will be final. See note 51 infra.

12. E.g., Moses v. The Mayor, 82 U.S. (15 Wall.) 387 (1872) (appeal of denial of motion to dissolve a temporary injunction dismissed where determination of merits remained). Orders relating to injunctions are generally not reviewable as final decisions unless leading to a dismissal. The Court has adopted the practice of dismissing appeals from such orders in short per curiam decisions. E.g., Williams v. Quill, 303 U.S. 621 (1938) (per curiam) ; Augusta Power Co. v. Savannah River Elect. Co., 284 U.S. 574 (1931) (per curiam).

13. Thus, the Court has stated that "a judgment to be appealable should be final not only as to all the parties, but as to the whole subject-matter and to all the causes of action involved. ..." Collins v. Miller, 252 U.S. 364, 370-71 (1920) ; Oneida Navigation Corp. v. W. \& S. Jacob Co., 252 U.S. 521 (1920). Another oft-quoted definition of finality, also indicating a good deal of rigidity in the application of finality, may be found in Bostwick v. Brinkerhoff, 106 U.S. 3, 4-5 (1882).

14. Williams v. Morgan, 111 U.S. 684 (1884).

15. Withenbury v. United States, 72 U.S. (5 Wall.) 819 (1866).

16. Clark v. Williard, 292 U.S. 112 (1934).

17. Crick, The Final Judgment as a Basis for Appeal, 41 Y $\mathrm{ALE}$ L.J. 539 (1932); Note, 48 HARV. L. REv. 302 (1934). Some states, purporting to apply the original chancery practice, allow appeal from interlocutory decrees in equity. E.g., Electric Research Prods., Inc. v. Vitaphone Corp., 20 Del. Ch. 417, 433, 171 Atl. 738, 745 (Sup. Ct. 1934) (construing DeI. Const. art. 4, \& 11(4) (1897)). This does not mean complete freedom of appeal, however, for in equity practice "interlocutory" is a word of art describing only orders by which "real and substantial rights were determined." Electric Research Prods., Inc. v. Vitaphone Corp., supra at p. 433.

Appeal in equity is generally more liberal. See, e.g., Miss. Cone ANN. $§ 1148$ (1956), which provides in part that in equity actions appeals "may in sound discretion be granted ... from any interlocutory order or decree ... when ... [the chancellor] may think an appeal proper in order to settle all the controlling principles involved in the cause, or in exceptional cases to avoid expenses and delay. . . " TENN. Code ANN. tit. 27, § 305 (1956). But see R. I. GeN. Laws \$ 9-24-1 (1956) (". . f final decree ... in any cause in equity. ..."). 
administration of estates and in receiverships (both equitable proceedings), for example, the continuing nature of the process and the numerous intermediate and important decrees prior to the "final" order, lead to judicial willingness to entertain pre-judgment appeals from a party who has seen all the questions in which he is interested terminated. ${ }^{18}$ Indeed, without the possibility of such appeals, receiverships might be unmanageable. ${ }^{10}$ The many orders relating to diverse parties and diverse subjects could not be reviewed until the receivership had terminated.

The strictness with which finality is required as a condition of review has also depended on the court system in which review is sought. Thus, there has been disparity as to the availability of review within a state court system, within the federal court system and from state courts to the United States Supreme Court. Review is perhaps most readily obtained within the appellate structure of the state court systems. Though there is a general requirement of finality as a condition to review, ${ }^{20}$ an elaborate system for review of interlocutory orders ${ }^{21}$ or discretionary certification of orders otherwise not final, ${ }^{22}$ is also usually found.

Finality imposes a somewhat greater obstacle to appeal within the federal system. As a prerequisite to appeal from district courts to courts of appeals, finality has been required by statute since the creation of the courts of appeals in $1891 .{ }^{23}$ Prior to that time it was a prominent, though not universal, feature

18. E.g., Central Trust Co. v. Grant Locomotive Works, 135 U.S. 207 (1890) (appeal by receiver of an order directing purchase of locomotives). For an extensive review of these multi-party, multi-issue cases, see Rector v. United States, 20 F.2d 845, 860-72 (8th Cir. 1927).

19. 6 Moore, Federal. Practice $\int 54.151$, at 142 (2d ed. 1953) : "Without this practical principle ['that any order made in receivership setting substantial rights; with no reservation as to its effect and designed to be operative at once was final'] a receivership would be unmanageable."

20. Ala. Code tit. 7, § 754 (1958); Artz. Rev. Stat. ANn. \$ 12-2101 (1956); Ark. Stat. ANn. tit. 27, $\S \S 2001,2101$ (1962) ; Conn. Gen. Stat. $\$ 52-263$ (1961 Supp.); Fla. Stat. Ann. $\$ 59.02$ (1962 Supp.); Mass. Ann. Laws ch. 214, 19 (1955); Mrss. Code Ann. $\S 1147$ (1942) ; N.J. Sup. Cr. R. 1:2-1 (1953) ; OkLA. Stat. AnN. tit. 12, \$\$ 951-52 (1961) ; Pa. Stat. Ann. tit. 12, § 1092 (1953); Utam Code Ann. tit. 78-2-2 (1953); VA. CODE § 8-462(1) (b) (1957).

21. Ala. Code tit. 7, § 755 (Supp. 1961); Ala. Code tit. 7, §\$ 757, 759 (1958); ArIz. Rev. Stat. AnN. \& 12-2101(F)(2), (G), and (H) (1956); Ark. Stat. Ann. tit. 27, \$2102 (1962); Mv. Code ANn. art. 5, \$ 7(a)-(d) (Supp. 1963); Mo. Code ANN. art. 5, \$ \& (1957); Orla. Stat. ANn. tit. 12, \& 952 (1951); N.J. Sup. Cr. R. $1: 2-3$ (1958); No. Dar. Code Ann. § 28-27-02 (1960); PA. Stat. Ann. tit. 12, § 1101 (1953); VA. Code Ann. \$ \$-462(1) (a) (1957); Wis. Stat. Ann. \$ 274.09(1) (1958). Exceptions are most frequently made in receivership proceedings, where an accounting is reserved, and for orders relating to injunctive relief.

22. Tex. Rev. Civ. Stats. Ann. tit. 37, art. 1729 (1962) provides for certification by the intermediate appellate courts under a number of circumstances "at any time ... [the intermediate appellate court] may choose, whether before or after the decision of the case in said Court." Cf. Mass. Ann. Laws ch. 231, § 111 (1956).

23. 28 U.S.C. \& 1291 (1958). 
of the relationship between the Supreme Court and the inferior federal courts. ${ }^{24}$ Since 1895 , however, certain of the more important and troublesome orders, notably injunctions, have been made appealable to the courts of appeals by statute. ${ }^{25}$ The relaxation of finality was carried even further by the Interlocutory Appeals Act of 1958, Section 1292(b) of the Code, which provides for appeals from any interlocutory decision which, in the combined discretion of the district court and the court of appeals, involves "a controlling question of law as to which there is substantial ground for difference of opinion ... [the immediate appeal of which] may materially advance the ultimate termination of the litigation. . ."26 In addition to purely statutory changes, Federal Rule of Civil Procedure 54(b) allows appeal from orders disposing of severable parts of litigation involving multiple claims or multiple parties. ${ }^{27}$ The area left to case law construction of the statutory term, "final decision," is no longer very large, and most litigation in the courts of appeals now revolves about the various statutes and rules which have amended former practice.

In review of the courts of appeals by the Supreme Court, the finality requirement is not emphasized in the statutory scheme. Section 1254, the principal section of the Code governing the relationship between these two levels, does not mention "finality." In fact, writs of certiorari and certified questions

24. E.g., Withenbury v. United States, 72 U.S. (5 Wall.) 819 (1866) (appeal from district court) ; Williams v. Morgan, 111 U.S. (15 Wall.) 684 (1884) (appeal from circuit court). In McLish v. Roff, 141 U.S. 661, 665-66 (1891), the Supreme Court read a statute governing its appellate jurisdiction over certain territorial courts to require finality, in the absence of an express provision.

25. 28 U.S.C. $\$ 1292$ (a) (1) (1958) makes appealable to the courts of appeals "Interlocutory orders . . granting, continuing, modifying, refusing or dissolving injunctions, or refusing to dissolve or modify injunctions. . ." 28 U.S.C. $\S 1292(2),(3)$, and (4) (1958), make appealable certain orders in receivership, admiralty, and patent proceedings. Injunctions were made appealable in 1895, 28 Stat. 666 (1895), as amended, 28 U.S.C. $\S 1292$ (a) (1) (1958); receivership orders in 1900 by 31 Stat. 660 (1900), as amended, 28 U.S.C. $\S 1292$ (a) (2) (1958); admiralty orders in 1926 by 44 Stat. 233 (1926), as amended, 28 U.S.C. $\$ 1292$ (a) (3) (1958); patent orders in 1927 by 44 Stat. 1261 (1927), as amended, 28 U.S.C. $\$ 1292$ (a) (4) (1958). The probable cause of these liberalizations was the harm to litigants from a denial of immediate appeal from such orders. Baltimore Contractors, Inc. v. Bodinger, 348 U.S. 176, 181 (1955). Comment, Discretionary Appeals of District Court Interlocutory Orders: A Guided Tour Through Section 1292(b) of the Judicial Code, 69 Y ALE L.J. 333, 339 (1959).

26. 28 U.S.C. \$ 1292(b) (1958).

27. Fed. R. Crv. P. 54(b) provides:

When more than one claim for relief is presented in an action ... or when multiple parties are involved, the court may direct the entry of a final judgment as to one or more but fewer than all of the claims or parties. ...

54(b) was a necessary corollary to the Rules which allowed greater joinder of claims and parties. See Note, 49 YALE L.J. 1476 (1940).

The adoption of the Rules by many states allows for a corresponding increase in appealability within state systems. E.g., Wyo. Sup. CT. R. 54(b) (1957). About one-half of the states have adopted a substantial part of the Federal Rules; about one-quarter have adopted them entirely. Clark, Two Decades of the Federal Civil Rules, 58 Colum. I. Rev. 435 (1958). 
under that section are explicitly made available prior to final judgment, ${ }^{28}$ although the Supreme Court has usually considered finality an important factor in exercising its discretion to grant certiorari. ${ }^{29}$ The other subsection of 1254 , providing for appeals from a decision holding that a state statute is invalid, has been construed to require finality as a condition of appeal..$^{30}$

The rules of finality are well-settled, and there has been little attempt to alter the doctrine towards greater permissiveness for review, even where such alteration would apparently serve the needs of both courts and parties. One universally recognized departure from this stringent attitude stems from Forgay $v$. Conrad. ${ }^{31}$ In that case, appeal was allowed from a decree which set aside certain deeds as fraudulent and ordered transfer of money, land and slaves, despite the fact that an order referred to a master an accounting of the profits on the land and slaves under the deed. The decree, however, entitled the plaintiff to immediate execution; the danger that the land and slaves might be sold led the court to the conclusion that a denial of appeal might result in irreparable injury. Forgay $v$. Conrad implicitly recognized that interlocutory orders might be given final effect where there was a sufficiently great threat of injury to litigants. ${ }^{32}$ Although the Forgay expansion of the finality rule might have been extended by analogy to a variety of situations, it has been narrowly restricted..$^{33} \mathrm{~A}$ characteristic of the residual accounting in Forgay was that it could neither moot appellant's federal claim nor create a new

28. Writ of certiorari is available "before or after rendition of judgment or decree." 28 U.S.C. $\$ 1254(1)$ (1958); certification "of any question of law" is available at any time. 28 U.S.C. $\$ 1254(3)$ (1958). The certification procedure, which dates from 1802, has never required finality. 2 Stat. 156, 159 (1802).

29. Robertson \& KIrkhaAr, JuRisdiction of THE SUPREMre Court of the UNITED States (2d ed. Wolfson \& Kurland 1951), § 130. Hamilton-Brown Shoe Co. v. Wolf Bros. \& Co., 240 U.S. 251, 258 (1916). Clearly, however, finality provides less of an obstacle to appeal here than where it is an explicit statutory requirement. See, e.g., United States v. General Motors Corp., 323 U.S. 373, 377 (1945) ; Land v. Dollar, 330 U.S. 731, 734 n.2 (1947).

30. ROBERTSON \& KRRKAM, op. cit. sutpra note 29, § 125; Slaker v. O'Connor, 278 U.S. 188 (1929). But cf. City of Chicago v. Atchison, Topeka \& Santa Fe Ry. Co., 357 U.S. 77 (1958).

31. 47 U.S. (6 How.) 201 (1848).

32. In Craighead v. Wilson, 59 U.S. (18 How.) 199 (1856), the Court conceded that Forgay involved an "interlocutory order," $i d$. at 202. In theory, however, decisions reviewable under Forgay are "final."

33. The Forgay doctrine has been restricted to cases where the order directs transfer of property, and some part of the case, almost invariably an accounting, remains. Thomson v. Dean, 74 U.S. (7 Wall.) 342 (1868) ; Carondolet Canal \& Navigation Co. v. Louisiana, 233 U.S. 362 (1914) ; Radio Station WOW v. Johnson, 326 U.S. 120 (1945); United States v. Certain Real Estate, 217 F.2d 920 (6th Cir. 1954); Kashiske v. Baker, 144 F.2d 385 (10th Cir. 1944); Pioche Mines Consolidated, Inc. v. Fidelity-Philadelphia Trust Co., 191 F.2d 399 (9th Cir. 1951) (alternative ground). See generally 6 MooRE, Federal Practice 【 54.13 (2d ed. 1953). Indeed, Forgay has been so narrowly confined that the relevance of its expansion of finality may be questioned. 
federal claim; for federal purposes, the litigation was plainly final. Only when the federal claim was in like posture has Forgay been applied. ${ }^{34}$

A more viable doctrine expanding the definition of finality is the collateral order doctrine. In Cohen v. Beneficial Industrial Loan Corp.,$^{35}$ the Supreme Court held appealable to a court of appeals as "final" a determination that a state statute requiring security to be posted in a shareholder's derivative suit did not apply to a federal district court sitting in that state. The decision in the Cohen case rested on at least three, possibly four, factors. ${ }^{36}$ As in Forgay, a denial of immediate review posed the danger of irreparable injury. ${ }^{37}$ In addition, Cohen required that the order then being appealed would not be reversible error when the merits of the cause of action were reviewed after entry of judgment. ${ }^{38}$ Finally, the Court indicated that review of a collateral order should be allowed only if the determination appealed from involved an important claim of right. What was needed to make a right "important," however, was left unclear. The Court plainly meant to require that the right asserted by the appellant be significant from the litigant's point of view. Beyond this, however, there is language which indicates that the question must also be of interest to the appellate court and, specifically, that it be an unsettled question. $^{39}$ Subsequent cases relying on Cohen bear out the statement that "importance" is to be determined from the appellate court's, as well as the litigant's, point of view. ${ }^{40}$

34. In Radio Station WOW v. Johnson, 326 U.S. 120, 127 (1945), the Court said of the Forgay cases:

The presupposition in allowing . . . review is that the federal questions that could come here have been adjudicated by the State court, and that the accounting which remains to be taken could not remotely give rise to a federal question. . . . Where the remaining litigation may raise other federal questions that may later come here, ... to allow review of an intermediate adjudication would offend the decisive objection to fragmentary review.

35. 337 U.S. 541 (1949). Cohen construed 28 U.S.C. \& 1291 (1958), defining the appellate jurisdiction of the federal courts of appeals. See generally Underwood, Appeals in the Federal Practice from Collateral Orders, 36 VA. L. REv. 731 (1950); 6 MOORE, Federal Practice ff 54.14 (2d ed. 1953).

36. United States v. Ceferatti, 202 F.2d 13, 16 (D.C. Cir. 1952), suggested threefinal irreparable effect, important claim of right, and collaterality.

37. When that time comes, [i.e., "final disposition of the merits"] it will be too late effectively to review ...., and the rights conferred by statute, if it is applicable, will have been lost, probably irreparably.

337 U.S. at 546 (1949).

38. Collaterality was the heart of the Cohen case. Since the order was collateral, in a sense a case within a case, it was a final decision within $\S 1291$, though not terminative of the litigation. The Court emphasized this distinction between a final and terminative order. "It is obvious that, if Congress had allowed appeals only from those final judgments which terminate an action, this order would not be appealable." 337 U.S. at 545 (1949). See Underwood, supra note 35, at 734.

39. ... we do not mean that every order fixing security is subject to appeal. Here it is the right to security that presents a serious and unsettled question. If the right were admitted or clear . . . appealability would present a different question.

337 U.S. at 547 (1949).

40. See, e.g., Brady v. Maryland, 373 U.S. 83, 85 n.1 (1963). 
Courts of appeals have been directed to use the collateral order doctrine in a wide variety of cases-civil, criminal ${ }^{41}$ or admiralty ${ }^{42}$-and have shown some initiative in exploring its implications for differing types of orders. ${ }^{43}$ The Supreme Court, however, has applied the doctrine only to orders relating to security (in a broad sense), as where an admiralty court orders that a foreign attachment be dissolved, ${ }^{44}$ or where a court refuses to apply a securityfor-expenses statute as in Cohen. The only development of the rule has been its application to cases where the appellant's claim of right was of a right not to post security ${ }^{45}$ or not to be liable for costs. ${ }^{46}$ Here the injury threatened seems to be less than in Cohen. Passage of the Interlocutory Appeals Act may presage a decline in the doctrine's vitality in federal courts, for the courts of appeals will certainly favor an explicitly discretionary approach to granting review, over a doctrine which appears to grant review as of right, but cloaks essentially discretionary judgments.

It is in the area of Supreme Court review of state court decision that finality requirements most restrict the availability of review. The mandate of Section 1257 permits appeal or petition for writ of certiorari only from "final judgments or decrees rendered by the highest court of a State in which the decision could be had. ..." Amendments or statutory exceptions to this rule have never been attempted, in striking contrast to the tendency toward statutory liberalization within the federal and state judiciaries. In case law interpretations of the term "final judgments or decrees," the Supreme Court appears never to have questioned that the same standards would apply under Section 1257 as apply to appeals from a federal district court to a court of

41. Stack v. Boyle, 342 U.S. 1 (1951); United States v. Foster, 278 F.2d 567 (2d Cir. 1960) ; United States v. Ceferatti, 202 F.2d 13 (D.C. Cir. 1952). But see Carroll v. United States, 354 U.S. 394 (1957), indicating that Cohen should be sparingly applied in criminal cases.

42. Swift \& Co. Packers v. Compania Columbiana Del Caribe, 339 U.S. 684 (1950).

43. Cohen has often been applied to orders relating to security. In Lee v. Western Wool Processors, Inc., 313 F.2d 13 (10th Cir. 1962), it was applied to an order seeking redeposit of a fund deposited in the court to stay execution of its judgment and withdrawn for alleged breach of the staying agreement. In Chabot v. National Securities \& Research Corp., 290 F.2d 657 (2d Cir. 1961), it was applied to an order staying proceedings until appellants gave security, and in Koster \& Wythe v. Massey, 262 F.2d 60 (9th Cir. 1958), it was applied to an order requiring payment of attachment costs to a United States Marshal after attachment had been dissolved, subject to dismissal with prejudice for failure to pay.

Cohen has also been applied to a consolidation order, MacAlister v. Guterma, 263 F.2d 65 (2d Cir. 1958) ; cf. Kelly v. Greer, 295 F.2d 18 (10th Cir. 1961); to the dismissal of a petition to intervene in the administration of an estate, Collins v. Miller, 198 F.2d 948 (D.C. Cir. 1952); to an order denying a motion to disqualify appellee's attorney, Tomlinson v. Florida Iron \& Metal, Inc., 291 F.2d 333 (5th Cir. 1961). Contra, Marco v. Dulles, 268 F.2d 192 (2d Cir. 1959).

44. Swift \& Co. Packers v. Compania Columbiana Del Caribe, 339 U.S. 684 (1950).

45. Stack v. Boyle, 342 U.S. 1 (1951).

46. Roberts v. United States Dist. Court, 339 U.S. 844 (1950). 
appeals. It has given the requirement a uniform interpretation regardless of whether the case has come from the federal courts or from state courts. Thus, although Forgay and Cohen were both decided in the federal system, their principles have been used in resolving questions of the reviewability of state court decisions without apparent recognition that such a use could be considered an extension of doctrine. ${ }^{47}$ In the absence of legislative liberalizations, the strict interpretation given to the finality requirement of Section 1257 has meant that appellate consideration of state court decisions has not been available prior to an ultimate judgment even when review is clearly desirable from the point of view of both courts and litigants.

In two cases decided last term, the Supreme Court bridged the gap, largely created by statutes, between the availability of Supreme Court review of state court decisions, and review within the state and federal systems. Applying what it identified as the Cohen doctrine to the Section 1257 finality rule, the Court fundamentally changed the finality requirement in the federal-state context. In the first case, Local 438 Construction Laborers' Union v. Curry, ${ }^{48}$ a construction company had sought temporary and permanent injunctive relief from Georgia courts for picketing allegedly in violation of the state's right-towork law. In addition to denying the illegality of its picketing, the union claimed that its activities were within the exclusive jurisdiction of the National Labor Relations Board. The court denied temporary relief. The Georgia Supreme Court, recognizing the denial as appealable, ${ }^{49}$ reversed, holding the refusal to issue the interlocutory injunction was erroneous, and thus permitting the union to return to the lower court to interpose new defenses..$^{50}$ The United States Supreme Court took the case on certiorari and held that the Georgia court's determination that it had jurisdiction to issue an injunction was a final decision under Section 1257, despite the possible revival of the case in the lower courts. ${ }^{51}$ Though under the theory of the Court's holding the merits of

47. Forgay was applied to state court judgments without any suggestion that a different standard should apply in Corondolet Canal \& Navigation Co. v. Louisiana, 233 U.S. 362 (1914). When the Cohen doctrine was first applied under $\$ 1257$ in Local 438, Construction Laborers' Union v. Curry, 371 U.S. 542 (1963), Harlan, J., who criticized the majority's position on finality, argued only that Cohen was distinguishable, and not that the standard of finality of $\S 1257$ was sufficiently different from that of $\S 1291$ to preclude applying Cohen; $i d$. at 44 (concurring opinion).

48. 371 U.S. 542 (1963).

49. The Curry case apparently went from the Superior Court to the Georgia Supreme Court under GA. CODE ANN. $\$ 903$ (1933), providing for "fast bills of exception" in cases granting or denying injunctive relief. The basic statute governing review of Superior Courts by the Georgia Supreme Court requires a "final disposition of the course" or that it be "final as to some material party thereto." GA. Code ANN. § 701 (1933).

50. $217 \mathrm{Ga} .512,123$ S.E.2d 653 (1962).

51. There was an alternative ground for the Supreme Court's decision on the finality issue. The Court, relying on Pope v. Atlantic Coast Line R. Co., 345 U.S. 379 (1953), held that though the effect of the Georgia Supreme Court's reversal was to allow the petitioner to return to the Superior Court and interpose new defenses, the decision was final since it did adjudicate all issues raised so far, and the petitioner asserted that it had 
the case-the legality of the union's picketing-had not been adjudicated, the jurisdictional issue would not have been passed upon again by the Georgia courts. ${ }^{52}$ Having determined the finality question, the Court reversed on the ground that the Georgia courts lacked jurisdiction to enjoin the labor activities in question.

On the same day, in Mercantile Nat'l Bank v. Langdeau, ${ }^{53}$ another opinion delivered by Mr. Justice White, the Supreme Court held "final" on appeal a determination by the Supreme Court of Texas ${ }^{54}$ that a federal statute fixing venue in suits against national banks was not mandatory, and, in any case, had been repealed by a later statute. The decision was rendered prior to a trial on the merits and, though recognized as interlocutory by Texas courts, had been made appealable by statute. ${ }^{.5}$ As in Curry, the Supreme Court relied on the fact that the venue question was finally decided within the Texas judicial system, and that it would be considered "law of the case" on subsequent ap-

no new defenses to make on remand. Local 438, Construction Laborers' Union v. Curry, 371 U.S. 542, 550 (1962).

At one time, the Court determined finality by the "face" of the judgment. E.g., Haseltine v. Central Bank, 183 U.S. 130, 131 (1901) ("We have . . . always made the face of the judgment the test of its finality. ..."). A somewhat similar rule made the "form" of the judgment dispositive. E.g., Louisiana Navigation Co. v. Oyster Comm., 226 U.S. 99, 101 (1912). Under either rule, Curry would not have been final because the "form" of the judgment in that case was a reversal and remand, and because to determine that there would be no further proceedings in the lower court on remand, the Court would have had to go beyond the "face" of the judgment. But the Court has rejected these standards for determining finality. E.g., City of Chicago v. Atchison, Topeka \& Santa Fe Ry., 357 U.S. 77 (1958) ; Pope v. Atlantic Coast Line R. Co., supra; Richfield Oil Corp. v. State Bd. of Equalization, 329 U.S. 69 (1946).

52. In reaching its decision on finality, the Court declined to follow Montgomery Bldg. \& Constr. Trades Council v. Ledbetter Erection Co., 344 U.S. 178 (1952). In that case the Court held not "final" a decision of a state supreme court affirming a denial of a motion to dissolve a temporary injunction issued to enjoin picketing. As in Curry, the petitioners in Montgomery asserted that the state courts had no jurisdiction. After Curry it would seem that Montgonery has little or no validity.

53. 371 U.S. 555 (1963).

54. Langdeau v. Republic Nat'l Bank, 161 Tex. 349, 341 S.W.2d 161 (1960) (Court of Civil Appeals opinion reported at 331 S.W.2d 349 (1959)).

55. The venue determination in Langdean was made appealable from the District Court to the Court of Civil Appeals by Tex. Rev. Crv. Stats. ANn. tit. 42, $\$ \$ 2007,2008$ (1950), which provide for a "plea of privilege" when an objection to venue is made and that "[e]ither party may appeal from the judgment sustaining or over-ruling the pleas of privilege. ..." This is an interlocutory decision and would not be appealable under the basic appeal statute, Tex. Rev. CIv. STAt. Ans. tit. 42, $\$ 2249$, which requires a "final judgment," in the absence of an excepting statute. Dougherty Grain Co. y. S. T. Oates Grain Co., 191 S.W.2d 804, 806 (1945).

Langdeau went to the Texas Supreme Court under Tex. Rev. Crv. Stats. AnN. tit. $37, \$ 1728$ (2) (1950), which defines the Supreme Court's jurisdiction to include decisions "in which one of the Courts of Appeals holds differently from a prior decision of another Court of Civil Appeals," and $\S 1729$, which allows certification of such a case "at any time [the Court of Civil Appeals] may choose, whether before or after the decision of the case. ..." 
peal. The Court then went on to reverse the Supreme Court of Texas and to hold that the federal venue statute applied.

To reach the result in Curry, the Court used both the collateral order doctrine and the Forgay doctrine, as applied to state court judgments in Radio Station WOW $v$. Johnson. ${ }^{58} \mathrm{Mr}$. Justice Harlan, disagreeing with the majority's reasoning while concurring in the result, pointed out, quite accurately, that both Cohen and Radio Station WOW were distinguishable. In Curry, unlike Cohen, the jurisdictional question would have been merged on final judgment. And, in Radio Station WOW, the accounting which was all that remained to be determined after decision on the merits could not have eliminated the necessity of deciding the federal questions raised. Further state court proceedings in Curry, however, might remove from controversy the federal question; for example, the injunction might not issue on the merits. In Langdeau, whose only authority on the issue of finality was Curry, Justice Harlan's critique was also valid-not only would the venue determination merge with the final judgment, but, were the appellants to triumph on the merits, as it appeared they well might, no need for resolution of the federal question would arise. Mr. Justice Harlan might also have added that in both cases, unlike Radio Station WOW, the part of the litigation which remained to be determined in the state courts could produce additional federal questions. In Curry, for example, petitioner argued that the application of the Georgia right-to-work law would be a violation of its right to free speech. In Langdeau, a large and complex case involving federal banks, it is hard to assert with any confidence that the determination of the merits would not produce any further federal questions.

Langdeau made explicit what was implicit in Curry, that a broad new test of Section 1257 finality - a test based on an expansion of Cohen's separateness test-was being used. The Court characterized the venue determination there held final as a "separate and independent matter, anterior to the merits, and not enmeshed in the factual and legal issues comprising the plaintiff's cause of action." 57 This test makes neither merger in the ultimate judgment nor the possibility that the federal questions will be eliminated in further proceedings disqualifications for review. It seems only to exclude cases where, because a determination appealed from could not be separated from the merits of the litigation, still pending before the state court, the Court in granting review would be passing on an issue which was not ripe for decision.

The new rule, then, has a wide sweep. Its requirements that an order challenged involve a claim of right, important to the litigant, and that injury be threatened, hardly limit that sweep. Under either the collateral order doctrine or Curry-Langdeau, the requirement that a claim be "important" seems to encompass any right conferred by statute or constitution. When state court decisions are to be reviewed, such a condition adds little to the statutory re-

56. 326 U.S. 120 (1945).

57. 371 U.S. $555,558$. 
quirements for Court jurisdiction. 58 Nor will "threat of injury," though more confining, significantly restrict the new doctrine. True, in Curry there was a high probability that an interlocutory injunction would break the strike, mooting the union's case. ${ }^{59}$ But Langdeau indicates that the threat of an unnecessary trial is sufficient to meet the requirement-even when review could ultimately be had if immediate review were denied. It is possible that Curry will have its greatest impact in the area of preemption in labor law; but since the Court analyzed the problem in jurisdictional terms, it may well be extended to other jurisdictional conflicts arising out of a comprehensive federal regulatory scheme-for example, the tangle of confusion characterizing relationships between the states and the Federal Power Commission since Phillips Petroleum Co. $v . W$ isconsin $^{60}$-with an attendant threat of frequent, dilatory appeals. Furthermore, there seems to be no barrier to extending the new doctrine to questions of personal jurisdiction, since challenges to personal jurisdiction are "anterior to the merits" and might result in the saving of a trial. ${ }^{.1}$

The breadth of Curry and Langdeau raises questions concerning the advisability of far-reaching case law changes in the final judgment rule. Confusion as to what is reviewable, the prospect of dilatory appeals, and the danger of overburdening the Supreme Court's dockets may outweigh the advantages of relaxing finality. ${ }^{62}$ There is no apparent limitation to seeking review under

58. In the lower federal courts, however, this requirement has excluded a number of cases from the collateral order doctrine. Fleischer v. Phillips, 264 F.2d 515 (2d Cir. 1959), ccrt. denied, 359 U.S. 1002 (1959) ; Kowalski v. Holden, 276 F.2d 359 (6th Cir. 1960) (no claim of right). Cf. United States v. Foster, 278 F.2d 567 (2d Cir. 1960) (order refusing to extend limits on bail appealable where based on constitutional claim).

59. The havoc which temporary injunctions play in labor disputes is well-known. See Michelman, State Power to Govern Concerted Employee Activities, 74 HARv. L. Rev. 641 649-50 (1961). The petitioners in Curry argued that in Georgia "a body of precedent is being established ... which is inconsistent with the decisions of the Supreme Court ... and no redress has been obtainable because ... said cases were always determined at the temporary injunction stage . . . and never reached final decision." Petition for Certiorari, p. 23.

60. 347 U.S. 672 (1954) ("independent" natural gas producers subject to the jurisdiction of the Federal Power Commission).

61. Cutrry and Langdeau suggest two additional limitations on their doctrine-that the appellant's claim to a right be substantial, and that the determination for which review is sought present an unsettled question. The former requirement is explicit in both opinions; the latter, though not clearly required by Langdeau, is suggested in both Cohen and Curry. Both requirements seem to put the determination of finality on a questionable doctrinal basis, for, although they certainly motivate the Court in granting review, they do not seem proper as elements of finality itself. Whether the determination presents an unsettled question or not, or whether appellant's arguments seem substantial or not, the posture of the decision in the state courts will be the same. And it is the posture in the state courts, rather than the desirability of present review, to which an analysis in terms of "finality" must be directed. Having determined a decision to be final, the Court might then decide to grant or to deny review, as it does in the usual instance, by reference to such factors as substantiality or unsettledness.

62. It is hard to estimate the specific effect of this relaxation of finality on the Court's dockets beyond noting that the number of appeals will be increased. The Court must 
the new doctrine, provided a federal question is presented, and provided state law renders the decision of which review is sought reviewable within the state system prior to ultimate judgment. Even though access to the Supreme Court can be no greater than access to state appellate courts, as a restriction on review this argument loses much of its force, since state systems are generally permissive in granting pre-judgment appeals. ${ }^{63}$

The Court might have avoided some of the weight on itself and litigants resulting from the Curry-Langdeau rule had it insisted that review of prejudgment decisions be obtained through either of two procedures utilizing prerogative writs. Under a line of precedent almost as old as the statutory finality requirement of Section 1257 , the denial of a prerogative writ by a state court-whether or not the writ is ancillary to other litigation-is a final judgment. ${ }^{64}$ If, therefore, the union in Curry had petitioned for a writ of prohibition from the Georgia Supreme Court immediately after the construction company had sought the injunction, ${ }^{65}$ and had the petition been denied, as would almost certainly have been the case, then there would have been a final judgment within the meaning of Section $1257 . .^{86}$ The union, of course, did not apply for a writ, and consequently this route to review was closed to it.

devote some of its time and energy to each case for which review is sought-whether the decision is final or not, and whether review is granted or not. Its workload, and the danger that litigants will be harassed by dilatory tactics (for which Court sanctions exist only in the most flagrant cases) are pro tanto increased. See Sup. Ct. R. 30(2), permitting addition of damages to the judgment when an appeal "appears to have been sued out merely for delay." Sup. Ct. R. 32(1) allows costs incident to the motion to dismiss to appellee or respondent when an appeal or writ of certiorari is dismissed for want of jurisdiction.

63. See notes 21-22 supra.

64. Writ of prohibition: Weston v. City Council, 27 U.S. (2 Pet.) 449 (1829); Mt. Vernon Cotton Co. v. Alabama Power Co., 240 U.S. 30 (1916) ; Missouri ex rel. St. Louis B. \& M. Ry. v. Taylor, 266 U.S. 200 (1924); Whittemore v. Farrington, 234 F.2d 221 (9th Cir. 1956) ; cf. Hammerstein v. Superior Court, 341 U.S. 491 (1951). Writ of mandamus: Detroit \& Mackinac Ry. v. Michigan R.R. Comm., 240 U.S. 564 (1916) ; Hartman v. Greenhow, 102 U.S. 672 (1880). Writ of habeas corpus : New York ex rel. Bryant v. Zimmerman, 278 U.S. 63 (1928).

65. GA. CodE ANN. tit. 64, §§ 301, 302 (1935), provides that prohibition "is the counterpart of mandamus, to restrain subordinate courts and inferior judicial tribunals from exceeding their jurisdiction, where no other legal remedy or relief is given ... [and that it] may be granted at anytime on proper showing made. . . ." It may be, however, that the availability of a "fast bill of exceptions" to review the Superior Court's order would have precluded the use of prohibition. On the other hand, the usual requirement for the issuance of a writ, that it not be used as a substitute for appeal, does not seem to be rigidly enforced in Georgia. E.g., City of Macon v. Anderson, 155 Ga. 607, 615 (1923), which held, as a matter of law, that the availability of certiorari would not preclude the use of prohibition.

66. "The proceeding for a writ of prohibition is a distinct suit, and a judgment finally disposing of it is a final judgment within the meaning of 28 U.S.C. 1257." Bandini Petroleum Co. v. Superior Court, 284 U.S. 8, 14 (1931).

On the possibility of a writ in the Montgomery case, note 50 supra, see the dissent in that case and Note, 51 Micr. L. Rev. 1070 (1953). 
But the litigants in Curry and Langdeau might also have sought writs from the Supreme Court to their respective state courts. Admittedly, the Supreme Court has used a writ to a state court only once, and then to enforce its mandate. ${ }^{67}$ But lack of precedent should not cast doubt on the Court's power to issue a writ, nor on the desirability of review by this method. The principle advantage of review by writ is that it is totally discretionary and confers no right to review. Review by prerogative writ, moreover, avoids a major difficulty caused by enlarging the definition of a final judgment or decree-the correlative necessity for all litigants to seek immediate review of orders falling within that definition, or lose their right to appeal. ${ }^{68} \mathrm{~A}$ frank admission that determinations such as those made in Langdeau and Curry were not final would likely have resulted in counsel seeking review in fewer, more meritorious cases. And it would also have made less harsh, from the perspective of potential impact on litigants, a restrictive attitude on the Court's part as to the decisions granted review prior to ultimate judgment.

Review by prerogative writ would also have avoided the question whether the Supreme Court's new definition of finality is to be applied by courts of appeals under the "final decision" requirement of Section 1291. Undoubtedly, appellants in the lower federal courts will try to use Curry-Langdeau to obtain review, for the cases would permit appeal by right in many situations in which the Interlocutory Appeals Act, together with Section 1291, presently requires joint exercise of discretion by a district court and a court of appeals. Although the Supreme Court, by conferring finality on a range of decisions almost as broad as is covered by the Interlocutory Appeals Act, may not have disturbed its own practice, the courts of appeals do not possess its discretion to refuse review of "final" decisions. Thus, to allow an appellant seeking review in a court of appeals to use Curry-Langdeau would undermine substantially the operation of the Interlocutory Appeals Act's mechanisms for discretionary review. The courts of appeals will surely attempt to find a way to avoid the precedent of Curry and Langdeau, exercising the same preference for discretion which suggests a diminution in their future use of the collateral order doctrine. But the doctrinal basis for excluding Curry and Langdeat from the lower federal courts can only be tenuous. The lower federal courts will be put in a position of denominating not "final" (thus not appealable) an order which is "final" under Section 1257; a difference between the finality requirement of Sections 1291 and 1257, heretofore unrecognized, will spring into being. Review by writ, because it makes no pretension to review only final decisions, would have avoided this dilemma.

A broader criticism, based on grounds of federalism, is suggested by the fact that Curry and Langdeau allowed review in the state-federal context of

67. Dean v. Hickman, 358 U.S. 57 (1958). Prior to that case there had been several suggestions that use of a writ to a state court would be inappropriate, e.g., In re Blake, 175 U.S. 114, 118 (1899), and even cases suggesting that the Court lacked power, e.g., In re Green, 141 U.S. 325, 327 (1891). But see 1 Moore, Federal Practice $\int$ 0.6[6] n.9, at 254 .

68. See note 7 supra. 
a class of determinations which a congressional enactment made appealable within the federal system, ${ }^{60}$ but not from state to federal systems. The very fact that the final judgment or decree requirement has rested unaltered in the Judicial Code since 1789, while finality requirements have been varied in other contexts, suggests that finality is partially a doctrine of federalism, and not solely a rule of convenience. This aspect of the finality rule becomes clearer if one remembers that increasing the review of determinations made prior to an ultimate or terminative judgment gives the reviewing federal court more power to effectuate its view of the law. ${ }^{70}$ Indeed, conflict between courts permeates the background of Curry and Langdeau. In Curry, for example, the Supreme Court's new rule may be seen as a way to make state court interference with federally-protected labor activities immediately reviewable. ${ }^{71}$ With one possible exception, however, past Supreme Court practice does not seem to demonstrate any concern with the ramifications for federalism of changes in the finality rule. ${ }^{2}$ Indeed, the Supreme Court has given finality the same definition

69. Of course, Curry would have been reviewable within the lower federal courts under 28 U.S.C. \& 1292(a) (1) (1958). If, however, Curry did not involve an injunction, but some order outside the scope of $\S 1292(\mathrm{a})$, then it would seem to fit squarely within the Interlocutory Appeals Act, 28 U.S.C. \& 1292(b). See Recent Statutes, 72 HARv. L. Rev. 584 (1959) ; S. ReP. No. 2434, 85th Cong., 2d Sess. 3 (1958); H.R. ReP. No. 1667, 85th Cong., 2d Sess. 2 (1958).

70. "The doctrine of finality is a phase of the distribution of authority within the judicial hierarchy." Cobbledick v. United States, 309 U.S. 323, 326 (1940).

71. See note 57 supra. In the Langdean case, the Supreme Court of Texas said:

[venue] is a matter where the state is exercising powers wholly within the domain of state interest, and is, therefore, insulated from federal judicial review as well as the application of federal venue statutes.

341 S.W.2d 161, 164 (1960).

72. Suggestions that federalism is involved in finality, limited to Justices Frankfurter and Harlan on the Court, seem to have the support of most commentators. Frankfurter, J., has said that finality "is especially pertinent when a constitutional barrier is asserted against a state court's decision on matters peculiarly of local concern." Republic Natural Gas Co. v. Oklahoma, 334 U.S. 62, 67 (1948). And, he has also stated, finality "derives added force when the jurisdiction of this Court is invoked to upset the decision of a state court." Radio Station WOW v. Johnson, 326 U.S. 120, 124 (1945). Republic Natural Gas is the only case where federalism may have materially influenced the decision as to finality. Harlan, J., dissenting in Mercantile Nat'l Bank v. Langdeau, 371 U.S. 555 (1963), said of finality: "That requirement is more than a technical rule of procedure, yielding when need be to the exigencies of particular situations. Rather it is a long-standing and healthy federal policy ... helping to keep to a minimum undesirable federal-state conflicts." Yet, he too seemed to assume that particular rules developed in federal cases would apply in evaluating the finality of state decisions as well, supra note 47.

ROBERTSON \& KIRKHAM, op. cit. supra note $29, \S 23$, p. 52, says that the requirement has been "given a unique construction" in $\S 1257$, and that cases construing the requirement in other statutes "are of doubtful authority on the interpretation of the requirement of finality in 1257." But see $i d . \S 28$, p. 57 n.3, p. 58 n.7, p. 59 n. 8 , p. 60 n. 11 , and $\S 29$, p. 62 , where the authors note that the precedent in particular areas is identical with that in the federal system. No authority is given for the proposition that $\$ 1257$ has been given a "unique" construction other than the Frankfurter opinions referred to above. Boskey, Finality of State Court Judgments under the Federal Judicial Cade, 43 Corun. L. REv. 
wherever found. ${ }^{73}$ Consequently, it is difficult to give specific content to any argument that federalism requires a narrow definition of finality in Section 1257. The argument is surely made difficult if, as in Curry and Langdeau, a state has tolerated appellate consideration of an order within its own judicial system; it is hard to believe that such a state could be offended by Supreme Court review of that order. Only were the Supreme Court's appellate review of state court judgments to be enlarged to a point where determinations deemed unreviewable in the state courts were held reviewable by the Court could the Court's action be said to impinge upon a sound policy of federalism. But the policy which would inhibit the Court from expanding pre-judgment review of state decisions beyond the limits which the state or its courts have set, has little relevance when these limits are honored.

If the Court's doctrine extended to the full range of decisions allowed review in state courts, it might allow review of decisions excludable on grounds of ripeness or justiciability. There is a point at which increased appellate consideration of determinations raised prior to ultimate judgment allows review of questions which are premature. It is possible that state courts and legislatures are less scrupulous in this regard than the Supreme Court has been. The argument, however, seems vitiated by the fact that in Curry and Langdeau the test of separateness was designed to ensure that the state court determination was one which could properly be reviewed within the Court's own standards. That is, the Court is not compelled to review decisions as final merely because they are reviewable under state law. Its own jurisprudence of ripeness and justiciability would operate to select from among these cases those it feels suitable for review. Such a process of selection is implicit in the two decisions considered.

Ultimately, therefore, the arguments against the Court's new interpretation of the finality requirement must be directed towards the administration of the rule. It is unfortunate for both courts and litigants if the pressure of appeals or petitions for review is increased to the point of blockage or harassment. It might have been preferable, both to avert some of this pressure and to avoid doctrinal difficulties in construing finality in the federal courts, for the Court to have insisted that any review of pre-judgment decisions in state courts be obtained by prerogative writ. But the Court is merely following the trend to increased use of interlocutory review within our judicial system-a tendency which can only be tested by experience. Assuming that the Court remains within the contours of federalism and justiciability, seemingly delineated by the Curry-Langdeau doctrine, its recent expansion should be accepted as a defensible redefinition of the finality requirement of Section 1257.

1002 (1943), follows RobERTSON \& KIRKHAMr, op. cit. supra, and finds a policy of avoiding excess review of state court decision in $\S 1257$. No authority is given.

In their certiorari petition, at p. 30, petitioners in Curry intimated the view that there were different standards applying to finality in the federal system as opposed to $\$ 1257$. This may explain why Cohen v. Beneficial Industrial Loan Corp., 337 U.S. 541 (1947), was not cited in the petitioner's brief, and was only barely mentioned in their certiorari petition, at p. 31.

73. Note 47 supra. 